\title{
PHYSICAL QUALITY OF AN OXISOL UNDER AN INTEGRATED CROP-LIVESTOCK-FOREST SYSTEM IN THE BRAZILIAN CERRADO ${ }^{(1)}$
}

\author{
Eurico Lucas de Sousa Neto( ${ }^{(2)}$, Itamar Andrioli( ${ }^{(3)}$, Roberto Giolo de Almeida ${ }^{(4)}$, Manuel \\ Cláudio Mota Macedo ${ }^{(4)}$ \& Rattan Lal ${ }^{(5)}$
}

\begin{abstract}
SUMMARY
Soil physical quality is an important factor for the sustainability of agricultural systems. Thus, the aim of this study was to evaluate soil physical properties and soil organic carbon in a Typic Acrudox under an integrated crop-livestock-forest system. The experiment was carried out in Mato Grosso do Sul, Brazil. Treatments consisted of seven systems: integrated crop-livestock-forest, with 357 trees ha-1 and pasture height of $30 \mathrm{~cm}\left(\mathrm{CLF}_{357-30}\right)$; integrated crop-livestock-forest with 357 trees ha-1 and pasture height of $45 \mathrm{~cm}\left(\mathrm{CLF}_{357-45}\right)$; integrated crop-livestockforest with 227 trees ha ${ }^{-1}$ and pasture height of $30 \mathrm{~cm}\left(\mathrm{CLF}_{227-30}\right)$; integrated croplivestock-forest with 227 trees $\mathrm{ha}^{-1}$ and pasture height of $45 \mathrm{~cm}\left(\mathrm{CLF}_{227-45}\right)$; integrated crop-livestock with pasture height of $30 \mathrm{~cm}\left(\mathrm{CL}_{30}\right)$; integrated croplivestock with pasture height of $45 \mathrm{~cm}\left(\mathrm{CL}_{45}\right)$ and native vegetation $(\mathrm{NV})$. Soil properties were evaluated for the depths of 0-10 and 10-20 cm. All grazing treatments increased bulk density $\left(\rho_{\mathrm{b}}\right)$ and penetration resistance (PR), and decreased total porosity $\left(f_{\mathrm{t}}\right)$ and macroporosity $\left(f_{\mathrm{ma}}\right)$, compared to $\mathrm{NV}$. The values of $\rho_{\mathrm{b}}\left(1.18-1.47 \mathrm{Mg} \mathrm{m}^{-3}\right), f_{\mathrm{ma}}\left(0.14-0.17 \mathrm{~m}^{3} \mathrm{~m}^{-3}\right)$ and PR (0.62-0.81 MPa) at the 0-10 $\mathrm{cm}$ depth were not restrictive to plant growth. The change in land use from NV to CL or CLF decreased soil organic carbon (SOC) and the soil organic carbon pool $\left(\mathrm{SOC}_{\text {pool }}\right)$. All grazing treatments had a similar $\mathrm{SOC}_{\text {pool }}$ at the 0-10 cm depth and were lower than that for NV (17.58 $\left.\mathrm{Mg} \mathrm{ha}^{-1}\right)$.
\end{abstract}

Index terms: agroforestry, soil organic carbon, multivariate analysis.

(1) Received for publication on May 28, 2013 and approved on November 5, 2013.

(2) Professor, Department of Animal Science, Universidade do Estado do Mato Grosso - Pontes e Lacerda. Rodovia MT 174, Km 209, Zona Rural. Postal Box 181. CEP 78250-000 Pontes e Lacerda (MT), Brazil. E-mail: euriconeto@unemat.br

(3) Professor, Department of Soil and Fertilizer, Universidade Estadual Paulista. Via de acesso Prof. Paulo Donato Castellane, s/ n. CEP 14884-900 Jaboticabal (SP), Brazil. E-mail: itamar@fcav.unesp.br

(4) Researcher, Centro Nacional de Pesquisa Gado de Corte, Embrapa - Gado de Corte. Rua Rádio Maia, 830, Zona Rural. CEP 79002-970 Campo Grande (MS), Brazil. E-mail: robertogiolo@cnpgc.embrapa.br, macedo@cnpgc.embrapa.br

(5) Professor, Carbon Management and Sequestration Center, Ohio State University. CEP 43210 Columbus, OH, USA. E-mail: lal.1@osu.edu 


\title{
RESUMO: QUALIDADE FÍSICA DE UM LATOSSOLO SOB INTEGRAÇÃO LAVOURA-PECUÁRIA-FLORESTA NO CERRADO BRASILEIRO
}

\begin{abstract}
A qualidade física do solo é um importante fator para a sustentabilidade dos sistemas agrícolas. O objetivo desta pesquisa foi avaliar as propriedades físicas do solo e o carbono orgânico em um Latossolo Vermelho distrófico, sob sistema de integração lavoura-pecuáriafloresta. O experimento foi conduzido no Mato Grosso do Sul, Brasil. Os tratamentos consistiram de sete sistemas: integração lavoura-pecuária-floresta, com 357 árvores ha ${ }^{-1} \mathrm{e}$ altura de pastejo de $30 \mathrm{~cm}\left(\mathrm{CLF}_{357-30}\right)$; integração lavoura-pecuária-floresta, com 357 árvores ha-1 e altura do pastejo de $45 \mathrm{~cm}\left(\mathrm{CLF}_{357-45}\right)$; integração lavoura-pecuária-floresta, com 227 árvores ha-1 e altura do pastejo de $30 \mathrm{~cm}\left(\mathrm{CLF}_{227-30}\right)$; integração lavoura-pecuáriafloresta, com 227 árvores ha-1 e altura do pastejo de $45 \mathrm{~cm}\left(\mathrm{CLF}_{227-45}\right)$; integração lavourapecuária, com a altura do pastejo de $30 \mathrm{~cm}\left(\mathrm{CL}_{30}\right)$; integração lavoura-pecuária, com a altura do pastejo de $45 \mathrm{~cm}\left(\mathrm{CL}_{45}\right)$; e vegetação nativa (NV). As propriedades do solo foram avaliadas nas profundidades de 0-10 e 10-20 cm. Todos os tratamentos com pastagem aumentaram a densidade do solo $\left(\rho_{\mathrm{b}}\right)$ e resistência à penetração $(\mathrm{RP})$ e diminuíram a porosidade total $\left(f_{\mathrm{t}}\right)$ e macroporosidade $\left(f_{\mathrm{ma}}\right)$, em comparação com a NV. Os valores de $\rho_{\mathrm{b}}\left(1,18-1,47 \mathrm{Mg} \mathrm{m}^{-3}\right), f_{\mathrm{ma}}\left(0,14-0,17 \mathrm{~m}^{3} \mathrm{~m}^{-3}\right)$ e PR $(0,62-0,81 \mathrm{MPa})$ na profundidade de $0-10 \mathrm{~cm}$ não foram restritivos ao crescimento de plantas. A mudança de uso do solo a partir $\mathrm{NV}$ para CL ou CLF diminuiu o carbono orgânico (SOC) e o estoque de carbono orgânico ( SOC $_{\text {pool }}$ ). Todos os tratamentos com pastagem apresentaram $\mathrm{SOC}_{\text {pool }}$ similar na profundidade de 0$10 \mathrm{~cm}$ e foram menores em comparação à $\mathrm{NV}\left(17,58 \mathrm{Mg} \mathrm{ha}^{-1}\right)$.
\end{abstract}

Termos de indexação: sistemas agroflorestais, carbono orgânico, análise multivariada.

\section{INTRODUCTION}

Increasing population and its demands have required drastic changes in agricultural systems. Traditional production systems have been replaced by environmentally, socially, and economically sustainable systems. However, projected climate changes demand even more drastic adaptive measures in agriculture production systems (IPCC, 2007).

Soils are integral to the sustainability of agricultural systems, and inappropriate management can jeopardize soil quality and sustainability. Land use with traditional agriculture involving excessive use of tillage and degradation of pasture are causing major ecological problems in the Brazilian savanna (Cerrado) and lead to nonsustainability of agricultural systems. However, use of complex systems involving a combination of annual crops and perennial grasses, or annual crops with perennial grasses and trees can restore degraded soils, increase production and improve the environment (Macedo, 2009).

Typically, the process of recovery of degraded soils by integrated crop-livestock or crop-livestock-forestry systems in the Brazilian Cerrado begins in autumn when the soil is tilled and prepared for growing annual crops (corn, soybean) in summer. The sequence continues with the cultivation of grass, or grass and trees, after the grain harvest. In some cases, there is intercropping of annual crops and grass, especially when the annual crop is corn (Borgui \& Crusciol, 2007). Livestock grazing occurs in winter and part of autumn; in summer, a no-till system (NT) is used for the production of annual crops.

Assessment of soil physical properties has indicated that integrating crop-livestock systems increases bulk density $\left(\rho_{\mathrm{b}}\right)$ and decreases total porosity $\left(f_{\mathrm{t}}\right)$ in the first grazing period (Araújo et al., 2010) but does not affect crop yield (Flores et al., 2007). Tracy \& Zhang (2008) reported an increase in penetration resistance (PR) and higher corn yield in an integrated croplivestock system after 5 years of use compared to continuous corn. These beneficial effects are attributed to a marked increase in soil organic carbon (SOC) concentration. Moreira et al. (2012) observed improvements in the physical quality of an Oxisol after 8 years of an integrated crop-livestock system and attributed it to the physical quality of resilience. In general, management practices induced changes in soil physical properties, which occur in surface soil (Conte et al., 2011a; Santos et al., 2011). The reversibility and intensity of soil physical degradation by animal trampling depend on grazing intensity (number of animals) and the height of the grass (Conte et al., 2011a). The intensity of soil compaction is related to pasture availability and manifestation of stress by the pasture biomass. Manifestation of stress is directly proportional to the amount of biomass on the soil (Braida et al., 2006).

In addition to pasture height, the factor of spatial arrangement of trees must be considered when they are introduced in integrated systems. The amount of sunlight reaching the soil surface in an agroforestry system depends on the growth and management of trees (Soares et al., 2009). Paciullo et al. (2010) observed a reduction of 22.3 and $41.4 \%$ in green forage 
and root mass, respectively, in the vicinity of the tree row compared to crop growth without trees.

Experiments carried out in some soils of the Brazilian Cerrado show that the use of an integrated crop-livestock (Carvalho et al., 2010) or eucalypt (Eucalyptus urograndis) forest (Zinn et al., 2011) system may enhance soil organic carbon (SOC) concentration. Lal (2004) reported that integration of crop, livestock and forest (agroforestry) systems can accentuate SOC sequestration. Increases in the SOC concentration and pool through the use of agroforestry systems, as reported by Paudels et al. (2012) in subtropical regions, as well as in some soils of tropical regions (Lima et al., 2011), have been attributed to higher root densities (Kumar et al., 2010),. However, most agroforestry studies involve fruit trees rather than timber wood species.

This study is based on the hypothesis that degradation of soil physical quality and change in the SOC concentration and pool in pastures are influenced by the presence and arrangement of trees and by the height of grass at the time of grazing. Thus, the aim of this study was to assess the soil physical properties and the SOC concentration and pool in a Typic Acrudox managed under crop-livestock and croplivestock-forest systems.

\section{MATERIALS AND METHODS}

\section{Site and treatments}

The study was carried out at the National Cattle Research Center of the Empresa Brasileira de Pesquisa Agropecuária (Brazilian Crop and Livestock Research Company), Mato Grosso do Sul, Brazil (Embrapa/ CNPGC). The climate is Aw according to the Köppen classification, with annual average rainfall of $1,500 \pm 227 \mathrm{~mm}$ and annual average temperature of $22.8^{\circ} \mathrm{C}$. Soil at the study site is classified as a Typic Acrudox, with $389 \pm 0.22 \mathrm{~g} \mathrm{~kg}^{-1}$ clay, $71 \pm 0.16 \mathrm{~g} \mathrm{~kg}^{-1}$ silt and $540 \pm 0.15 \mathrm{~g} \mathrm{~kg}^{-1}$ sand.

Soil analyses were performed for seven croplivestock systems as follows:

Integrated crop-livestock-forest $\left(\mathrm{CLF}_{357-30}\right)$ : This sequence commenced with the cultivation of soybean (Glycine max L.) from November 2008 to March 2009. Beginning in January 2009, grain crops were grown in the summer in association with eucalypt at a density of 357 trees ha $^{-1}(14 \mathrm{~m}$ between rows and $2 \mathrm{~m}$ between trees). In addition, palisade grass (Urochloa brizantha Piatã) was sown (4 kg ha-1) after soybean harvest. Animals were introduced into the system in May 2010 when the trees reached $7 \mathrm{~cm}$ in diameter and the palisade grass was $30 \mathrm{~cm}$ high;

Integrated crop-livestock-forest $\left(\mathrm{CLF}_{357-45}\right)$ : The sequence used in this treatment was the same as in the $\mathrm{CLF}_{357-30}$ treatment, except that the pasture height was $45 \mathrm{~cm}$;
Integrated crop-livestock-forest $\left(\mathrm{CLF}_{227-30}\right)$ : The sequence used in this treatment was the same as in the $\mathrm{CLF}_{357-30}$ treatment, except that there were 227 trees ha ${ }^{-1}(21 \mathrm{~m}$ between rows and $2 \mathrm{~m}$ between trees), and pasture height was $30 \mathrm{~cm}$;

Integrated crop-livestock-forest $\left(\mathrm{CLF}_{227-45}\right)$ : The sequence used in this treatment was the same as in the $\mathrm{CLF}_{227-30}$ treatment, except that the pasture height was $45 \mathrm{~cm}$;

Integrated crop-livestock $\left(\mathrm{CL}_{30}\right)$ : The sequence was cultivation of soybean (November 2008 to March 2009) followed by palisade grass. In April 2010, grazing animals were introduced into the grass with a height of $30 \mathrm{~cm}$;

Integrated crop-livestock $\left(\mathrm{CL}_{45}\right)$ : This sequence is the same as in $\mathrm{CL}_{30}$, except that the pasture height was $45 \mathrm{~cm}$; and

Native vegetation (NV): This was an undisturbed site under native vegetation typical to the savanna (Cerrado).

The area occupied by treatments $\mathrm{CLF}_{357-30}$, $\mathrm{CLF}_{357-45}, \mathrm{CLF}_{227-30}, \mathrm{CLF}_{227-45}, \mathrm{CL}_{30}$ and $\mathrm{CL}_{45}$ had been cleared in 1980 and was grazed continuously for 27 years. In 2008, prior to establishment of present experiment, the site was plowed, and recommended practices were implemented for all crops (Bungenstab, 2012).

All treatments including grass were grazed by cattle of the Nelore breed with individual weight of about $160 \mathrm{~kg}$. The number of animals varied depending on the desired grass height. The area of each experimental plot was about 1.5 ha.

\section{Measurement and analyses}

Soil samples were obtained in January 2011. Seven bulk and seven core samples were obtained from the 0-10 and 10-20 cm depths at each site.

Aggregate stability was determined by the wet sieving method (Nimmo \& Perkins, 2002). Fifty grams of air-dried aggregates at a size of 4.75-8.00 $\mathrm{mm}$ were placed on top of a nest of sieves of 4.75 , $2.00,1.00,0.50$ and $0.25 \mathrm{~mm}$ size and oscillated vertically at 30 oscillations per minute for $30 \mathrm{~min}$. The fractions retained on each sieve were separated and oven dried at $105^{\circ} \mathrm{C}$ for $24 \mathrm{~h}$. The percent of water stable aggregates (WSA) in each size were calculated according to equation 1 :

$$
W S A=\left(\frac{w i}{\sum w i}\right) * 100
$$

where $w i$ is the weight of the aggregates in each size classification (g).

The cores of $100 \mathrm{~cm}^{3}$ volume $(5.04 \mathrm{~cm}$ diameter and $5 \mathrm{~cm}$ height) were saturated for $48 \mathrm{~h}$ and subjected to pressures of 0 and $0.006 \mathrm{MPa}$ using a tension table (Romano et al., 2002), and 0.01 MPa using a pressure 
chamber (Dane \& Hopmans, 2002). After desorption at $0.01 \mathrm{MPa}$, the soil cores were removed from the pressure chamber and were oven dried at $105^{\circ} \mathrm{C}$ to determine soil bulk density $\left(\rho_{\mathrm{b}}\right.$ (Grossman \& Reinsch, 2002). Grab samples, collected from an area adjacent to where the soil-core samples were obtained, were air dried and crushed to pass through a $2 \mathrm{~mm}$ sieve. Soil particle density $\left(\rho_{\mathrm{s}}\right)$ was measured by the pycnometer method (Flint \& Flint, 2002). The average $\rho_{\mathrm{s}}$ of 98 soil samples (seven treatments $\times$ two depths $\times$ seven replications) was $2.58+0.09 \mathrm{Mg} \mathrm{m}^{-3}$. Soil total porosity $\left(f_{\mathrm{t}}\right)$ was determined by equation 2 . Microporosity $\left(f_{\mathrm{mi}}\right)$ was estimated corresponding to volumetric moisture content at $0.006 \mathrm{MPa}$ suction in the tension table according to the method of Embrapa (2011), and macroporosity $\left(f_{\mathrm{ma}}\right)$ (pores with equivalent diameter $>50 \mu \mathrm{m}$ ) was determined by the difference between $f_{\mathrm{t}}$ and $f_{\mathrm{mi}}$.

$$
f t=1-\left(\frac{\rho_{b}}{\rho_{s}}\right)
$$

where $\rho_{\mathrm{b}}$ is soil bulk density, and $\rho_{\mathrm{s}}$ is particle density $\left(\mathrm{Mg} \mathrm{m}^{-3}\right)$.

Soil cores at an equilibrium of water potential of $0.01 \mathrm{MPa}$ (corresponding to field moisture capacity) were wrapped in a cellophane membrane and stored in a refrigerator $\left(5{ }^{\circ} \mathrm{C}\right)$ for 5 days to homogenize soil moisture content. Penetration resistance (PR) was then measured in two replications for each core using a static electronic cone penetrometer with a cone angle of $30^{\circ}$ and basal area of $0.1167 \mathrm{~cm}^{2}$ at a constant penetration speed of $1 \mathrm{~cm} \mathrm{~min}{ }^{-1}$. This device was equipped with a $20-\mathrm{kg}$ load cell coupled to a microcomputer for data input (Tormena et al., 1998).

The SOC concentration was determined by the potassium dichromate $\left(\mathrm{K}_{2} \mathrm{Cr}_{2} \mathrm{O}_{7}\right)$ oxidation method at 170-180 ${ }^{\circ} \mathrm{C}$, followed by titration with $0.1 \mathrm{~mol} \mathrm{~L}^{-1}$ ferrous sulfate (Walkley \& Black, 1934). The SOC pool $\left(\mathrm{SOC}_{\mathrm{pool}}\right)$ was computed on an equal mass basis by using NV as a reference soil (Ellert \& Bettany, 1996) and was calculated by using equation 3 :

SOCpool $=\left[\mathrm{SOC}_{\text {layer }} * \rho_{\text {blayer }} *\right.$ Depth $\left.* 10^{-3} * 10^{-4}\right]$

where $\mathrm{SOC}_{\text {pool }}$ is expressed in $\mathrm{Mg} \mathrm{ha}^{-1}$, SOC is in $\mathrm{kg} \mathrm{Mg}^{-1}, \rho_{\mathrm{b}}$ is bulk density in $\mathrm{Mg} \mathrm{m}^{-3}$, and depth of the soil layer is in $\mathrm{m}$.

\section{Statistical analyses}

The experimental site including all seven treatments and seven replications was located on land with homogeneous topographic and edaphic-climatic conditions. The data were analyzed using a completely randomized factorial design and seven replications.

The $\mathrm{F}$ test was used to determine the significance of the main effects by computing ANOVA. Significant differences among treatments were established using the least significant difference (LSD) $(p<0.05)$.
The multivariate structure was examined by hierarchical cluster analysis and principal component analysis (PCA). For cluster analyses, data standardization was performed in order to provide null means and variance equal to one for each sample. The Euclidean distance was used as a dissimilarity distance (Sneath \& Sokal, 1973). Ward's method was used as the grouping technique (Ward, 1963).

In this study, analysis was made of principal components with eigenvalues $>1$ (Kaiser, 1958). Bidimensional representation was created with the principal components for better visualization of the structure of specific soil properties and treatments.

\section{RESULTS}

\section{Soil physical properties}

All grazing treatments increased soil $\rho_{\mathrm{b}}$, and decreased $f_{\mathrm{t}}$ and $f_{\mathrm{ma}}$ compared to $\mathrm{NV}(\mathrm{p}<0.05)$ (Table 1). At the $0-10 \mathrm{~cm}$ depth, the treatments with animal grazing had similar $\rho_{\mathrm{b}}$, with values ranging from 1.18 to $1.32 \mathrm{Mg} \mathrm{m}^{-3}$, i.e., from around 25 to $40 \%$ higher than that of $\mathrm{NV}\left(0.94 \mathrm{Mg} \mathrm{m}^{-3}\right)$. The use of trees did not cause differences in $\rho_{\mathrm{b}}$ at the $0-10 \mathrm{~cm}$ depth. At the $10-20 \mathrm{~cm}$ depth, the $\rho_{\mathrm{b}}$ of treatments with trees $\left(\mathrm{CLF}_{357-30}, \mathrm{CLF}_{357-45}, \mathrm{CLF}_{227-30}\right.$ and $\left.\mathrm{CLF}_{227-45}\right)$ ranged from 1.30 to $1.45 \mathrm{Mg} \mathrm{m}^{-3}$, which was from 15 to $65 \%$ higher than those for CL $\left(\mathrm{CL}_{30}\right.$ and $\left.\mathrm{CL}_{45}\right)$ and NV, respectively. The increase in $\rho_{\mathrm{b}}$ at the $10-20 \mathrm{~cm}$ depth was accompanied by a reduction in $f_{\mathrm{t}}$. Although $f_{\mathrm{ma}}$ also decreased, lower value of $f_{\mathrm{ma}}\left(0.07 \mathrm{~m}^{3} \mathrm{~m}^{-3}\right)$ was observed in $\mathrm{CLF}_{357-30}$. The less $f_{\mathrm{mi}}$ was found in NV for two depths -0.30 and $0.32 \mathrm{~m}^{3} \mathrm{~m}^{-3}$. At the $0-10 \mathrm{~cm}$ depth, $f_{\mathrm{mi}}$ was similar for the $\mathrm{CL}_{30}\left(0.39 \mathrm{~m}^{3} \mathrm{~m}^{-3}\right)$ and $\mathrm{CL}_{45}\left(0.38 \mathrm{~m}^{3} \mathrm{~m}^{-3}\right)$ treatments; these values were higher than those for the other treatments (Table 1).

Soil PR was greater in all the grazing treatments, and it was lower at the $0-10 \mathrm{~cm}$ depth than at the $10-20 \mathrm{~cm}$ depth. For the $0-10 \mathrm{~cm}$ depth, treatments with trees and the lower pasture height of $\mathrm{CLF}_{357-30}$ $(0.81 \mathrm{MPa})$ and $\mathrm{CLF}_{227-30}(0.88 \mathrm{MPa})$ had higher PR values than those for other treatments, and they were 279 and $303 \%$ higher than the value for NV. For the 10-20 cm depth, the $\mathrm{CLF}_{357-30}$ and $\mathrm{CLF}_{227-30}$ treatments had the highest PR; the values observed of 0.92 and $0.96 \mathrm{MPa}$ were 438 and $457 \%$ higher, respectively, than the value for $\mathrm{NV}$ (Table 2).

At the $0-10 \mathrm{~cm}$ depth, WSA were different among treatments for the 4.67-8.00 and 2.00-4.76 mm size classes. The $\mathrm{CLF}_{357-30}$ treatment had higher WSA (95\%) in the 4.76-8.0 mm class, but lower (1.28\%) in the 2.00-4.76 mm size range. For the $10-20 \mathrm{~cm}$ depth, $\mathrm{CLF}_{357-30}$ had a higher WSA (92.43 \%) in the 4.76$8.00 \mathrm{~mm}$ size class and $\mathrm{CL}_{30}$ had a higher WSA in all other size classes (Table 3). 
Table 1. Soil bulk density $\left(\rho_{\mathrm{b}}\right)$, total porosity $(f \mathrm{t})$, macroporosity $(f \mathrm{ma})$ and microporosity $(f \mathrm{mi})$ at the soil depths and in the treatments studied

\begin{tabular}{|c|c|c|c|c|c|c|c|c|}
\hline \multirow{2}{*}{ Treatment } & \multicolumn{4}{|c|}{ 0-10 cm depth } & \multicolumn{4}{|c|}{$10-20 \mathrm{~cm}$ depth } \\
\hline & $\rho_{\mathrm{b}}$ & $f \mathrm{t}$ & $f \mathrm{ma}$ & $f \mathrm{mi}$ & $\rho_{\mathrm{b}}$ & $f \mathrm{t}$ & $f \mathbf{m} \mathbf{a}$ & $f \mathrm{mi}$ \\
\hline & $\mathrm{Mg} \mathrm{m}^{-3}$ & 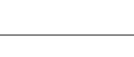 & $-\mathrm{m}^{3} \mathrm{~m}^{-3}$ & & $\mathrm{Mg} \mathrm{m}^{-3}$ & 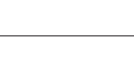 & $-\mathrm{m}^{3} \mathrm{~m}^{-3}$ & \\
\hline $\mathrm{CLF}_{(357-30)}$ & $1.30 \mathrm{Aa}$ & $0.51 \mathrm{Abc}$ & $0.15 \mathrm{Ab}$ & $0.36 \mathrm{Abcd}$ & $1.45 \mathrm{Aa}$ & $0.44 \mathrm{Ad}$ & $0.07 \mathrm{Ac}$ & $0.37 \mathrm{Aab}$ \\
\hline $\mathrm{CLF}_{(357-45)}$ & $1.32 \mathrm{Aa}$ & $0.50 \mathrm{Ac}$ & $0.16 \mathrm{Ab}$ & $0.34 \mathrm{Aabc}$ & $1.39 \mathrm{Aab}$ & 0.47 Acd & $0.13 \mathrm{Abc}$ & $0.34 \mathrm{Ab}$ \\
\hline $\mathrm{CLF}_{(227-30)}$ & $1.22 \mathrm{Aa}$ & $0.53 \mathrm{Abc}$ & $0.16 \mathrm{Ab}$ & 0.37 Acd & $1.30 \mathrm{Aab}$ & $0.52 \mathrm{Abc}$ & $0.15 \mathrm{Ab}$ & $0.37 \mathrm{Aab}$ \\
\hline $\mathrm{CLF}_{(227-45)}$ & $1.25 \mathrm{Aa}$ & $0.52 \mathrm{Abc}$ & $0.19 \mathrm{Ab}$ & $0.33 \mathrm{Aab}$ & $1.34 \mathrm{Aab}$ & $0.55 \mathrm{Abc}$ & $0.17 \mathrm{Ab}$ & $0.38 \mathrm{Aab}$ \\
\hline $\mathrm{CL}_{(30)}$ & $1.20 \mathrm{Aa}$ & $0.54 \mathrm{Abc}$ & $0.15 \mathrm{Ab}$ & $0.39 \mathrm{Ad}$ & $1.19 \mathrm{Ab}$ & $0.54 \mathrm{Abc}$ & $0.14 \mathrm{Ab}$ & $0.40 \mathrm{Aa}$ \\
\hline $\mathrm{CL}_{(45)}$ & $1.18 \mathrm{Aa}$ & $0.55 \mathrm{Ab}$ & $0.17 \mathrm{Ab}$ & $0.38 \mathrm{Ad}$ & $1.18 \mathrm{Ab}$ & $0.54 \mathrm{Abc}$ & $0.17 \mathrm{Ab}$ & $0.37 \mathrm{Aab}$ \\
\hline $\mathrm{NV}$ & $0.94 \mathrm{Ab}$ & $0.64 \mathrm{Aa}$ & $0.32 \mathrm{Aa}$ & $0.32 \mathrm{Aa}$ & $0.83 \mathrm{Ac}$ & $0.63 \mathrm{Aa}$ & $0.33 \mathrm{Aa}$ & $0.30 \mathrm{Ab}$ \\
\hline
\end{tabular}

Mean values with the same uppercase letter in the depth and lowercase letter in the treatment do not differ among themselves by the LSD test $(p<0.05)$.

Table 2. Penetration resistance and soil water content at the soil depths and treatments studied

\begin{tabular}{|c|c|c|c|c|}
\hline \multirow{2}{*}{ Treatment } & \multicolumn{2}{|c|}{ Penetration resistance } & \multicolumn{2}{|c|}{ Water content (100 MPa) } \\
\hline & $0-10 \mathrm{~cm}$ & $10-20 \mathrm{~cm}$ & $0-10 \mathrm{~cm}$ & $10-20 \mathrm{~cm}$ \\
\hline & & 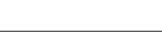 & 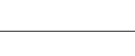 & \\
\hline $\mathrm{CLF}_{(357-30)}$ & $0.81 \mathrm{Abc}$ & $0.92 \mathrm{Ad}$ & 0.22 & 0.22 \\
\hline $\mathrm{CLF}_{(357-45)}$ & $0.62 \mathrm{Ab}$ & 0.87 Acd & 0.21 & 0.20 \\
\hline $\mathrm{CLF}_{(227-30)}$ & $0.88 \mathrm{Ac}$ & $0.96 \mathrm{Ad}$ & 0.23 & 0.25 \\
\hline $\mathrm{CLF}_{(227-45)}$ & $0.64 \mathrm{Abc}$ & $0.76 \mathrm{Abcd}$ & 0.23 & 0.23 \\
\hline $\mathrm{CL}_{(30)}$ & $0.62 \mathrm{Ab}$ & $0.67 \mathrm{Abc}$ & 0.30 & 0.28 \\
\hline $\mathrm{CL}_{(45)}$ & $0.63 \mathrm{Abc}$ & $0.63 \mathrm{Ab}$ & 0.27 & 0.27 \\
\hline $\mathrm{NV}$ & $0.29 \mathrm{Aa}$ & $0.21 \mathrm{Aa}$ & 0.30 & 0.28 \\
\hline
\end{tabular}

Mean values with same uppercase letter at the depth and lowercase letter in the treatment do not differ among themselves in the LSD test $(p<0.05)$.

Table 3. Water stable aggregate size distribution at the depths and in the treatments studied

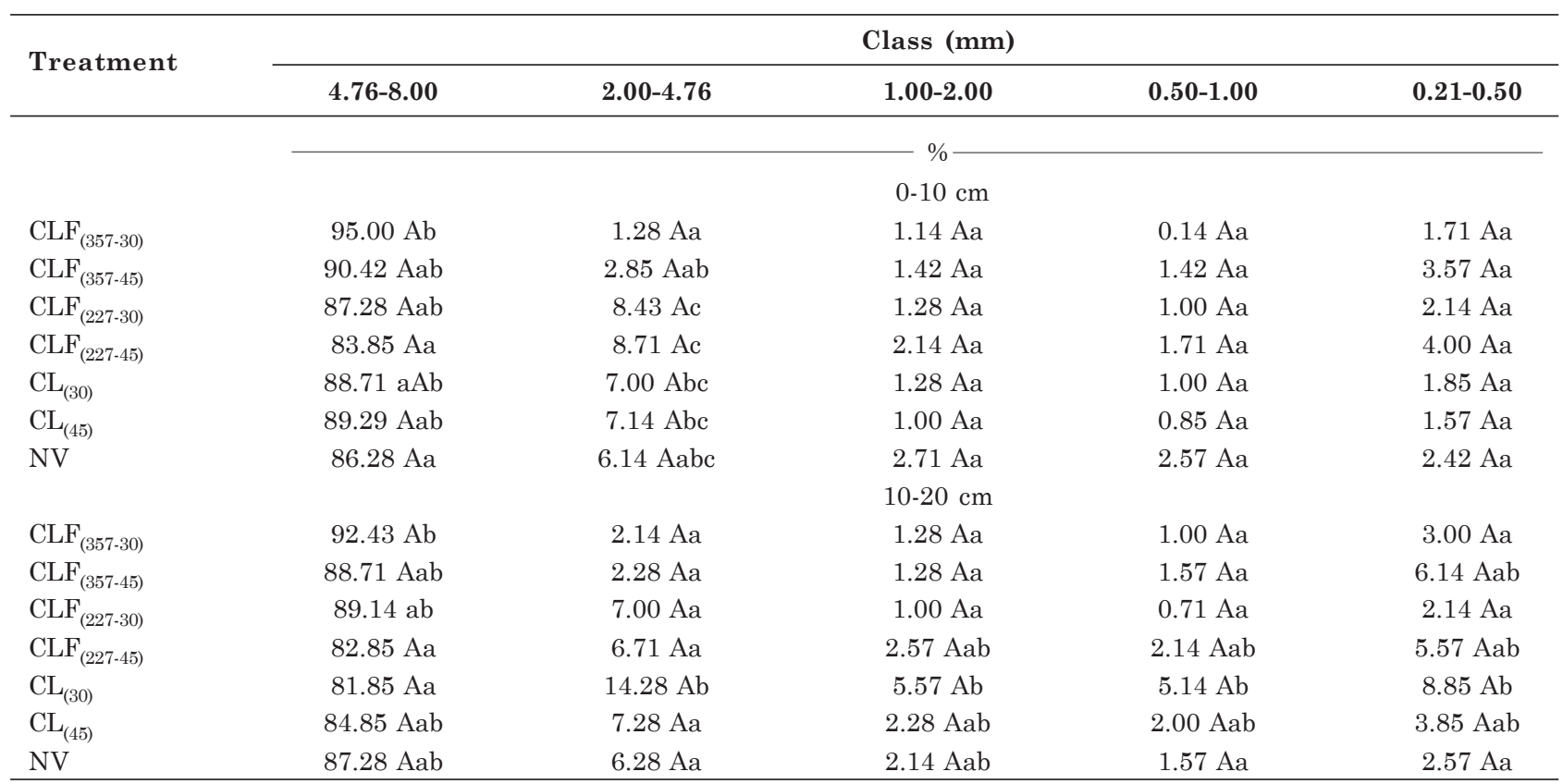

Mean values with the same uppercase letter at the depth, and lowercase letter in the treatment do not differ among themselves in the LSD test $(\mathrm{p}<0.05)$. 


\section{Soil organic carbon concentration and pool}

The change in land use from NV to CL or CLF decreased the SOC and $\mathrm{SOC}_{\text {pool }}(\mathrm{p}<0.05)$ (Table 4). For the $0-10 \mathrm{~cm}$ depth, treatments with trees $\left(\mathrm{CLF}_{357-30}\right.$, $\mathrm{CLF}_{357-45}, \mathrm{CLF}_{227-30}$ and $\mathrm{CLF}_{227-45}$ ) tended to have lower SOC than those without trees (though statistically not different). All grazing treatments had a similar $\mathrm{SOC}_{\text {pool }}$ in the $0-10 \mathrm{~cm}$ depth, and values were lower than the value for NV $\left(17.58 \mathrm{Mg} \mathrm{ha}^{-1}\right)$. In the 10-20 cm depth, however, CLF $_{357-30}$ with $11.64 \mathrm{Mg} \mathrm{ha}^{-1}$ and $\mathrm{CLF}_{227-30}$ with $11.49 \mathrm{Mg}^{-1} \mathrm{ha}^{-1}$ had lower values for $\mathrm{SOC}_{\text {pool }}$; the values were about $16 \%$ lower than the value for $\mathrm{NV}$. The sum of $\mathrm{SOC}_{\text {pool }}$ at both depths for $\mathrm{CLF}_{357-30}\left(24.67 \mathrm{Mg} \mathrm{ha}^{-1}\right), \mathrm{CLF}_{357-45}$ (25.32 $\left.\mathrm{Mg} \mathrm{ha}^{-1}\right)$ and $\mathrm{CLF}_{227-45}\left(25.61 \mathrm{Mg} \mathrm{ha}^{-1}\right)$ were lower than $\mathrm{SOC}_{\text {pool }}$ for $\mathrm{NV}\left(31.28 \mathrm{Mg} \mathrm{ha}^{-1}\right)$ and other treatments (Table 4).

\section{Multivariate analyses}

Assessment of similarity using cluster analysis based on the dendogram suggests the occurrence of three different clusters (Figure 1). The first cluster consists only of NV. The second cluster consists of treatments involving integrated crop-livestock systems $\left(\mathrm{CL}_{30}\right.$ and $\left.\mathrm{CL}_{45}\right)$. The third cluster includes treatments with crop-livestock-forest combinations $\left(\mathrm{CLF}_{357-45}, \mathrm{CLF}_{227-45}, \mathrm{CLF}_{357-30}\right.$, and $\left.\mathrm{CLF}_{227-30}\right)$ (Figure 2).

The use of 24 soil properties in PCA identified three factors with eigenvalues $>1$, and 19 soil properties with factor loading $>0.75$. These factors explained $89.01 \%$ of variance in measured soil properties (Table 5). Principal component 1 (PC1) explained $51.66 \%$ of the variation and had high factor loading for 11 soil properties: $\rho_{\mathrm{b}}, f_{\mathrm{t}}, f_{\mathrm{ma}}, \mathrm{PR}$ (at the $0-10$ and 10-20 cm depths) and WSA $0.5-1 \mathrm{~mm}, \mathrm{SOC}$ and $\mathrm{SOC}_{\text {pool }}$ at the $0-10 \mathrm{~cm}$ depth. PC2 explained 17.87 $\%$ of the variation and had high factor loading for $\mathrm{WSA}_{4.76-8.00 \mathrm{~mm}}, \mathrm{WSA}_{2.00-4.76 \mathrm{~mm}}, \mathrm{WSA}_{1.00-2.00 \mathrm{~mm}}$, WSA $_{0.50-1.00 \mathrm{~mm}}, \mathrm{WSA}_{0.21-0.50 \mathrm{~mm}}$ at the $10-20 \mathrm{~cm}$ depth and $f_{\mathrm{mi}}$ at the $0-10 \mathrm{~cm}$ depth. PC3 had high factor loading for $\mathrm{WSA}_{0.21-0.50 \mathrm{~mm}}$ at the $0-10 \mathrm{~cm}$ depth.

Two dimensional representations of PC1 and PC2 showed similar trends of cluster analysis. The formation of three clusters made it possible to identify the treatments together with soil properties (Figure 3 ). With negative values and towards the left of CP1 was the NV treatment, for soil properties such as $f_{\mathrm{ma}}$ at the 0-10 and $10-20 \mathrm{~cm}$ depths and $f_{\mathrm{t}}, \mathrm{WSA}_{1.00-2.00}$, $\mathrm{WSA}_{0.50-1.00}$ and $\mathrm{SOC}_{\text {pool }}$ at the 0-10 cm depth. On the right side of the graph with positive values for PC1 included treatments involving crop-livestock-forest for PR and $\rho_{\mathrm{b}}$ at the 0-10 and 10-20 cm depths and $\mathrm{WSA}_{4.76-8.00}$ and $\mathrm{WSA}_{0.21-0.50}$ at the 0-10 $\mathrm{cm}$ depth. On the lower side of the graph, negative values of PC2 were established for the $\mathrm{CL}_{30}$ and $\mathrm{CL}_{45}$ treatments and for $f_{\mathrm{mi}}$ at the $0-10$ and $10-20 \mathrm{~cm}$ depths, $\mathrm{SOC}_{\text {pool }}$ at the $10-20 \mathrm{~cm}$ depth, and $\mathrm{WSA}_{2.00-4.76}$ and $\mathrm{WSA}_{2.00-0.50}$ at the 0-10 $\mathrm{cm}$ depth (Figure 3).

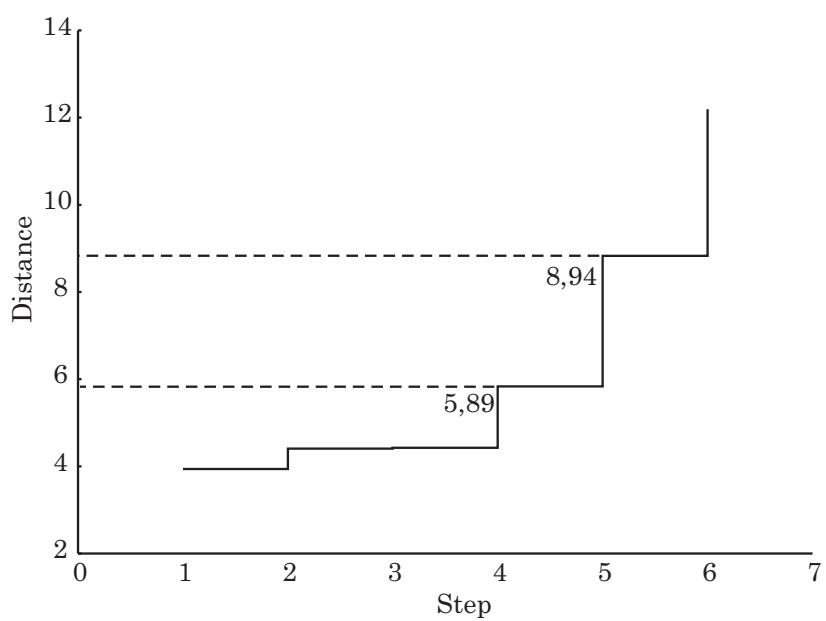

Figure 1. Representation of the significant variation of the Euclidean distance between the variables considered to be allowing the separation of groups.

Table 4. Soil organic carbon (SOC) and soil organic carbon pool (SOC $\mathrm{pool}_{\text {) }}$ at the soil depths and treatments studied

\begin{tabular}{|c|c|c|c|c|c|}
\hline \multirow{2}{*}{ Treatment } & \multicolumn{2}{|c|}{ SOC } & \multicolumn{2}{|c|}{$\mathrm{SOC}_{\text {pool }}$} & \multirow{2}{*}{$\begin{array}{c}\text { Total } \\
0-20 \mathrm{~cm}\end{array}$} \\
\hline & $0-10 \mathrm{~cm}$ & $10-20 \mathrm{~cm}$ & $0-10 \mathrm{~cm}$ & $10-20 \mathrm{~cm}$ & \\
\hline & \multicolumn{2}{|c|}{$\mathrm{g} \mathrm{kg}^{-1}$} & \multicolumn{3}{|c|}{$-\mathrm{Mg} \mathrm{ha}^{-1}$} \\
\hline $\mathrm{CLF}_{(357-30)}$ & $27.42 \mathrm{Aa}$ & $24.57 \mathrm{Aab}$ & $13.03 \mathrm{Aa}$ & $11.64 \mathrm{Aa}$ & $24.67 \mathrm{a}$ \\
\hline $\mathrm{CLF}_{(357-45)}$ & 28.14 Aab & 25.14 Aabc & $13.36 \mathrm{Aa}$ & 11.96 Aab & $25.32 \mathrm{a}$ \\
\hline $\mathrm{CLF}_{(227-30)}$ & 27.57 Aab & $24.14 \mathrm{Aa}$ & $14.12 \mathrm{Aa}$ & $11.49 \mathrm{Aa}$ & $25.61 \mathrm{a}$ \\
\hline $\mathrm{CLF}_{(227-45)}$ & 29.42 Aab & 25.71 Aabcd & $14.02 \mathrm{Aa}$ & 12.23 Aabc & $26.25 \mathrm{ab}$ \\
\hline $\mathrm{CL}_{(30)}$ & $31.42 \mathrm{Ab}$ & $29.28 \mathrm{Ad}$ & $14.96 \mathrm{Aa}$ & $13.93 \mathrm{Ac}$ & $28.89 \mathrm{bc}$ \\
\hline $\mathrm{CL}_{(45)}$ & $30.14 \mathrm{Aab}$ & 28.00 Abcd & $14.96 \mathrm{Aa}$ & 13.32 Aabc & $28.28 \mathrm{ab}$ \\
\hline NV & $37.85 \mathrm{Ac}$ & 28.71 Acd & $17.58 \mathrm{Ab}$ & $13.70 \mathrm{Abc}$ & $31.28 \mathrm{c}$ \\
\hline
\end{tabular}

Mean values with the same uppercase letter at the depth and lowercase letter in the treatment do not differ among themselves in the LSD test $(\mathrm{p}<0.05)$. 


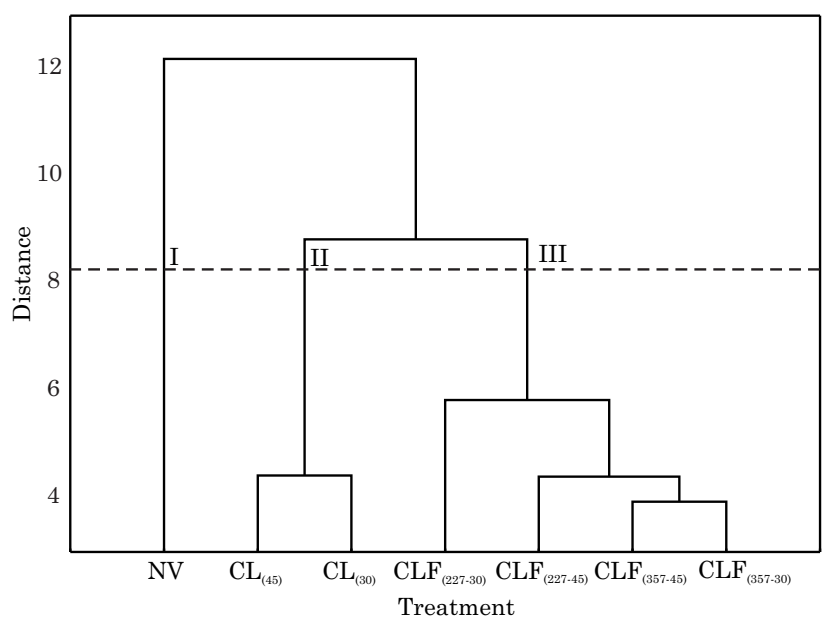

Figure 2. Dendogram of warm method showing similarities in soil physical attributes, SOC and $\mathrm{SOC}_{\text {pool }}$ in all treatments.

Table 5. Eigenvalues, \% variance, cumulative \% of variance and correlation between each principal component and soil attributes (bulk density BD; total porosity - TP; Macroporosity - Ma; Microporosity - Mi; penetration resistence - PR; water stable aggregation - WSA; soil organic carbon - SOC)

\begin{tabular}{|c|c|c|c|}
\hline Principal component & PC 1 & PC2 & PC3 \\
\hline Eigenvalue & 12.40 & 5.47 & 3.48 \\
\hline$\%$ of variance & 51.66 & 22.82 & 14.52 \\
\hline Cumulative \% of variance & 51.66 & 74.48 & 89.01 \\
\hline BD $0-10 \mathrm{~cm}$ & 0.98 & -0.04 & 0.00 \\
\hline BD $10-20 \mathrm{~cm}$ & 0.99 & 0.05 & -0.03 \\
\hline TP $0-10 \mathrm{~cm}$ & -0.97 & 0.07 & -0.04 \\
\hline TP $10-20 \mathrm{~cm}$ & -0.93 & -0.20 & 0.07 \\
\hline Ma $0-10 \mathrm{~cm}$ & -0.90 & 0.39 & 0.04 \\
\hline $\mathrm{Ma} 10-20 \mathrm{~cm}$ & -0.96 & 0.14 & 0.15 \\
\hline Mi $0-10 \mathrm{~cm}$ & 0.34 & -0.79 & -0.17 \\
\hline Mi $10-20 \mathrm{~cm}$ & 0.63 & -0.50 & -0.25 \\
\hline PR 0-10 cm & 0.79 & -0.27 & 0.52 \\
\hline PR $10-20 \mathrm{~cm}$ & 0.96 & -0.04 & 0.26 \\
\hline $\mathrm{WSA}_{4.76-8.00 \mathrm{~mm}} 0-10 \mathrm{~cm}$ & 0.51 & 0.21 & -0.71 \\
\hline $\mathrm{WSA}_{4.76-8.00 \mathrm{~mm}} 10-20 \mathrm{~cm}$ & 0.32 & 0.84 & -0.38 \\
\hline $\mathrm{WSA}_{2.00-4.76 \mathrm{~mm}} 0-10 \mathrm{~cm}$ & -0.36 & -0.46 & 0.38 \\
\hline $\mathrm{WSA}_{2.00-4.76 \mathrm{~mm}} 10-20 \mathrm{~cm}$ & -0.37 & -0.84 & -0.02 \\
\hline $\mathrm{WSA}_{1.00-2.00 \mathrm{~mm}} 0-10 \mathrm{~cm}$ & -0.71 & 0.31 & 0.56 \\
\hline $\mathrm{WSA}_{1.00-2.00 \mathrm{~mm}} 10-20 \mathrm{~cm}$ & -0.29 & -0.87 & -0.01 \\
\hline $\mathrm{WSA}_{0.50-1.00 \mathrm{~mm}} 0-10 \mathrm{~cm}$ & -0.78 & 0.18 & 0.56 \\
\hline $\mathrm{WSA}_{0.50-1.00 \mathrm{~mm}} 10-20 \mathrm{~cm}$ & -0.19 & -0.88 & -0.03 \\
\hline $\mathrm{WSA}_{0.21-0.50 \mathrm{~mm}} 0-10 \mathrm{~cm}$ & 0.11 & 0.17 & 0.94 \\
\hline $\mathrm{WSA}_{0.21-0.50 \mathrm{~mm}} 10-20 \mathrm{~cm}$ & 0.12 & -0.76 & 0.28 \\
\hline SOC $0-10 \mathrm{~cm}$ & -0.96 & 0.15 & -0.20 \\
\hline SOC $10-20 \mathrm{~cm}$ & -0.71 & -0.35 & -0.51 \\
\hline $\mathrm{SOC}_{\text {pool }} 0-10 \mathrm{~cm}$ & -0.96 & 0.00 & -0.23 \\
\hline $\mathrm{SOC}_{\text {pool }} 10-20 \mathrm{~cm}$ & -0.73 & -0.35 & -0.49 \\
\hline
\end{tabular}

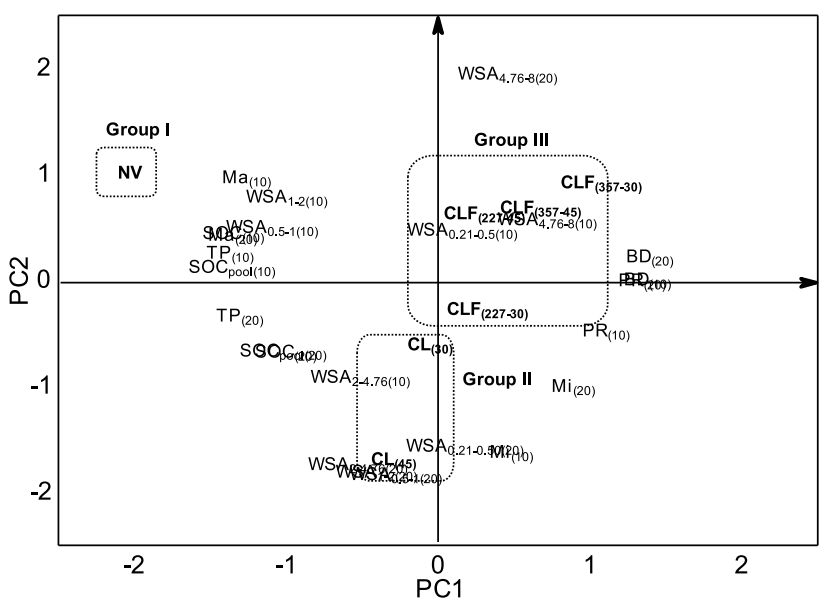

Figure 3. Biplot of principal components PC1 and PC2 of the principal component analysis with all soil samples and variables: bulk density 0-10 cm $\left(\mathrm{BD}_{10}\right)$, 10-20 cm $\left(\mathrm{BD}_{20}\right)$; total porosity 0-10 cm $\left(\mathrm{TP}_{10}\right), 10-20 \mathrm{~cm}\left(\mathrm{TP}_{20}\right)$; macroporosity 0-10 cm $\left(\mathrm{Ma}_{10}\right), 10-20 \mathrm{~cm}$ $\left(\mathrm{Ma}_{20}\right)$; microporosity 0-10 cm $\left(\mathrm{Mi}_{10}\right), 10-20 \mathrm{~cm}$ $\left(\mathrm{Mi}_{20}\right)$; penetration resistance $0-10 \mathrm{~cm}\left(\mathrm{PR}_{10}\right)$, $10-20 \mathrm{~cm}\left(\mathrm{PR}_{20}\right)$; water stability aggregate 4.76 8.00 mm, 0-10 cm (WSA $4,76-8.00(10)), 2.00-4.76 \mathrm{~mm}$,

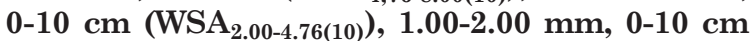
$\left(W_{S A} A_{1.00-2.00(10)}\right), 0.50-1.00 \mathrm{~mm}, 0-10 \mathrm{~cm}$ $\left(\mathrm{WSA}_{0.50-1.00(10)}\right), 0.21-0.50 \mathrm{~mm}, 0-10 \mathrm{~cm}$ $\left(\mathrm{WSA}_{0.21-0.50(10)}\right), 0$ 4.76-8.00 $\mathrm{mm}, 10-20 \mathrm{~cm}$ $\left(\mathrm{WSA}_{4,76-8.00(20)}\right), 2.00-4.76 \mathrm{~mm}, 10-20 \mathrm{~cm}$ $\left(\mathrm{WSA}_{2.00-4.76(20)}\right), 1.00-2.00 \mathrm{~mm}, 10-20 \mathrm{~cm}$ $\left(\mathrm{WSA}_{1.00-2.00(20)}\right), 0.50-1.00 \mathrm{~mm}, 10-20 \mathrm{~cm}$ $\left(\mathrm{WSA}_{\text {0.50-1.00(20) }}\right), 0.21-0.50 \mathrm{~mm}, 10-20 \mathrm{~cm}$ (WSA $\left.A_{0.21-0.50(20)}\right)$; soil organic carbon $0-10 \mathrm{~cm}$ $\left(\mathrm{SOC}_{10}\right), 10-20 \mathrm{~cm}\left(\mathrm{SOC}_{20}\right)$; soil organic carbon pool 0-10 cm $\left(\mathrm{SOC}_{\text {pool10 }}\right)$ and 10-20 $\mathrm{cm}$ $\left(\mathrm{SOC}_{\text {pool20}}\right)$.

\section{DISCUSSION}

\section{Soil physical properties}

Management induced changes in soil physical properties for crop-livestock systems compared to soil physical properties for the NV were also reported by Santos et al. (2011), especially for the surface soil. The values of $\rho_{\mathrm{b}}\left(1.18-1.47 \mathrm{Mg} \mathrm{dm}^{-3}\right)$, $f_{\text {ma }}$ (0.14-0.17 $\left.\mathrm{m}^{3} \mathrm{~m}^{-3}\right)$ and $\mathrm{PR}$ (0.62-0.81 MPa) observed at the $0-10 \mathrm{~cm}$ depth are not necessarily restrictive to plant growth (Xu et al., 1992; Reichert et al., 2009). These data are in accord with the data reported by Marchão et al. (2007), and support the conclusion that the integrated crop-livestock system is sustainable for the Brazilian Cerrado.

Increases in PR were a consequence of increases in $\rho_{\mathrm{b}}$, showing that $f_{\mathrm{t}}$ is affected by animal trampling, corroborating the results of Pietola et al. (2005) but differing from those reported by Fernández et al. (2011), who attributed the increase in $\rho_{\mathrm{b}}$ and PR in 
the soil surface in the crop-livestock system to the natural hardening process. Clayey soils, as was the case in this study, are more susceptible to compaction than sandy soils. Thus, it is important to consider all factors involved in the process of soil compaction. Rosseti et al. (2012) reported that the desirable level of soil moisture content for optimum soil compaction for a soil with $340 \mathrm{~g} \mathrm{~kg}^{-1}$ of clay is from 0.13 to $0.19 \mathrm{~kg} \mathrm{~kg}^{-1}$. Soil moisture content in this study was $>0.22 \mathrm{~kg} \mathrm{~kg}^{-1}$, for a matric potential of $<10 \mathrm{MPa}$.

The data on soil physical properties for CLF or CL systems indicate favorable soil physical quality. These favorable trends may be due to the effect that soil samples were obtained during the second year after establishing the treatments. In general, drastic adverse effects on soil physical properties by animal trampling in crop-livestock systems normally occur during the first grazings, and decrease over time (Moreira et al., 2012). Better soil physical quality observed in CLF or CL may be attributed to soil resilience and restoration by wetting and drying cycles and root growth (Gregory et al., 2007). The CL (soybean and palisade) and CLF (eucalypt, soybean and palisade) systems with greater species diversity may have a better root system (Kumar et al., 2010), with a beneficial impact on soil physical quality. Silva et al. (2011) observed that two years is an optimum time for management of a crop-livestock system for improving soil physical properties.

Similar or higher WSA in the 4.76-8.00 mm size class for treatments involving palisade compared to NV indicated the importance of grass in enhancing soil aggregation (Carvalho et al., 2010). Inda Júnior et al. (2007) reported that grasses can have an important function in formation of large aggregates by cementing together of micro aggregates. A relatively low effect of animal grazing on aggregates (1.0-2.0, 0.5-1.0 and 0.21-0.50 $\mathrm{mm}$ ) was also reported by Souza et al. (2010) for an Oxisol under an integrated crop-livestock system. It is possible that the forces that hold particles together in small aggregates are higher than those for larger aggregates because of higher protection of organic matter in small size aggregates.

The data of the present study indicated a higher WSA in a crop-livestock-forestry system $\left(\mathrm{CLF}_{357-30}\right.$ and $\mathrm{CLF}_{357-45}$ ) than for other systems. These results are in accord with those of Lenka et al. (2012) from central India, who also reported a higher WSA in soils under forest based pasture. Tree roots can penetrate deeper into the soil compared to those of annual crops (Mekonnen et al., 1997) and they release enzymes, which accentuate the aggregation process (Paudels et al., 2012).

\section{Soil organic carbon concentration and pool}

A higher SOC concentration in soils with pasture compared to those under NV and eucalypt forest have been reported by Pulrolnik et al. (2009). Such trends are attributed to a prolific root system and more biomass on the surface soil under grass. An average difference of $2.15 \mathrm{~g} \mathrm{~kg}^{-1}$ of SOC concentration between CLF and CL treatments may be attributed to the loss of dry matter from forage by grazing and, consequently, to the loss of the root system. Established trees (eucalypt) alter the microclimate near the grass and affect that development. Soares et al. (2009) reported a decline in dry matter yield of some grasses when planted between the rows of pine (Pinus taeda).

Changes in $\mathrm{SOC}_{\text {pool }}$ upon conversion of $\mathrm{NV}$ to pasture in the Brazilian Cerrado have also been reported by Maia et al. (2009). Reduction in $\mathrm{SOC}_{\text {pool }}$ in the present study by $23 \%\left(3.95 \mathrm{Mg} \mathrm{ha}^{-1}\right)$ and $15 \%$ (2.62 $\left.\mathrm{Mg} \mathrm{ha}{ }^{-1}\right)$ for CLF and the CL, respectively, compared to NV are more than the values reported for an Oxisol in central Brazil by Zinn et al. (2005). However, the $\mathrm{SOC}_{\text {pool }}$ of 13.63 and $14.96 \mathrm{Mg} \mathrm{ha}^{-1}$ at the 0-10 cm depth for CLF and CL, respectively, are similar to those reported for degraded pasture by Carvalho et al. (2010). Furthermore, the $\mathrm{SOC}_{\text {pool }}$ under the crop-livestock system increased over time.

Soil samples in the present study were obtained two years after the conversion of degraded pasture to CLF or CL. Thus, the $\mathrm{SOC}_{\text {pool }}$ may have increased over the 2-year period. For example, Tonucci et al. (2011) reported an increase in the SOC $_{\text {pool }}$ in CLF systems after 14 years of establishment, and the $\mathrm{SOC}_{\text {pool }}$ in CLF was similar to values of soils under pasture for 33 years and for native vegetation.

\section{Multivariate analyses}

The formation of three clusters indicated the grouping of treatments by management (NV, CL and CLF) rather than by the height of the grass. These trends are similar to those reported by Conte et al. (2011a), who also did not observe any difference in soil physical properties because of pasture height in the crop-livestock systems in an Oxisol in Brazil. It is probable that the palisade height (30 and $45 \mathrm{~cm}$ ) is sufficient to minimize the adverse effects of trampling by the cattle. Souza et al. (2010) also did not observe any degradation in soil structure when the height of grazing of black oat (Avena nativa) + Italian ryegrass (Lolium multiflorum Lam.) was about $20 \mathrm{~cm}$.

Both graphic presentation and correlation coefficients indicate that favorable soil physical quality under NV (group 1, in cluster analysis) is associated with higher $f_{\mathrm{ma}}$ and $f_{\mathrm{t}}$ at the $0-10$ and $10-20 \mathrm{~cm}$ depths and SOC and $\mathrm{SOC}_{\text {pool }}$ at the $0-10 \mathrm{~cm}$ depth (Table 4). Furthermore, higher $\rho_{\mathrm{b}}$ and PR at the 0-10 and 10-20 $\mathrm{cm}$ depths are useful indicators for separating CLF treatments (group 3, in cluster analysis). Tormena et al. (1998) also observed that management can easily change PR as a soil physical attribute, and any differences in PR can be measured immediately after pasture establishment (Conte et al., 2011b). 
Naturally, pastures are heterogeneous in the amount and quality of forage. Paciullo et al. (2011) observed the formation of a shadow zone by trees in agroforestry systems; the shadow zone near the tress has a smaller amount of forage, but it is of better quality (higher crude protein); and the zone away from the tree has a higher amount of forage, but of poorer quality. Animals seek better forages, which in CLF systems is in a zone parallel to and between the trees. Therefore, higher trampling by animals increased soil $\rho_{\mathrm{b}}$ between the tree rows.

The SOC concentration and $\mathrm{SOC}_{\text {pool }}$ at the 10-20 $\mathrm{cm}$ depth are index soil properties for characterizing group 2 (CL). For $\mathrm{C}$ input by the root system, some CLF treatments may have a larger root density than others. The growth of tree species eucalypts lower, Kuzyakov \& Domansky (2000) reported that grasses could sequester $\mathrm{SOC}_{\text {pool }}$ at the rate of $2.2 \mathrm{Mg} \mathrm{ha}^{-1}$ year-1 C. Furthermore, SOC and $\mathrm{SOC}_{\text {pool }}$ at the $0-20 \mathrm{~cm}$ depth can also differentiate group 2 (CL) because the yield of palisade with trees is less than the yield without trees (Paciullo et al., 2011). There is a strong relationship between yield and the root system. Both of these scenarios are in agreement with the hypothesis reported by Carvalho et al. (2010) that palisade has a deep root system and adds biomass$\mathrm{C}$ to the surface layers.

\section{CONCLUSIONS}

1. The hypothesis that the presence of trees in pastures affects soil physical properties and SOC concentration and $\mathrm{SOC}_{\text {pool }}$ is indicated by the data presented by multivariate analyses. Changes in soil physical properties by CLF or CL were not significant under the soil and management conditions of this experiment. Thus, crop-livestock systems can be used for long-term sustainability.

2. Additionally, long-term studies are needed to examine a range of combinations of trees, grasses and cropping systems. The potential of integrated croplivestock-forest systems must be observed for diverse soils and ecoregions.

\section{LITERATURE CITED}

ARAÚJO, F.S.; SALVIANO, A.A.C.; LEITE, L.F.C.; SOUZA, Z.M. \& SOUSA, A.C.M. Physical quality of a Yellow Latossol under integrated crop-livestock-system. R. Bras. Ci. Solo, 34:717-723, 2010.

BORGUI, E. \& CRUSCIOL, C.A.C. Produtividade de milho, espaçamento e modalidade de consorciação com Brachiaria brizantha em sistema plantio direto. Pesq. Agropec. Bras., 42:163-171, 2007.
BRAIDA, J.A.; REICHERT, J.M.; VEIGA, M. \& REINERT, D.J. Resíduos vegetais na superfície e carbono orgânico do solo e suas relações com a densidade máxima obtida no ensaio Proctor. R. Bras. Ci. Solo, 30:605-614, 2006.

BUNGENSTAB, D.J. Sistemas de integração lavourapecuária-floresta: A produção sustentável. 2.ed. Campo Grande, Embrapa Gado de Corte, 2012. 239p.

CARVALHO, J.L.N.; RAUCCI, G.S.; CERRI, C.E.P.; BERNOUX, M.; FEIGL, B.J.; WRUCK, F.J. \& CERRI, C.C. Impact of pasture, agriculture and crop-livestock systems on soil C stocks in Brazil. Soil Till. Res., 110:175$186,2010$.

CONTE, O.; WESP, C.L.; ANGHINONI, I.; CARVALHO, P.C.F.; LEVEIN, R. \& NABINGER, C. Densidade, agregação e fração de carbono de um Argissolo sob pastagem natural submetida a níveis de ofertas de forragem por longo tempo. R. Bras. Ci. Solo, 35:579-587, 2011a.

CONTE, O.; FLORES, J.P.C.; CASSOL, L.C.; ANGHINONI, I.; CARVALHO, P.C.F.; LEVEIN, R. \& WESP, C.L. Evolução de atributos físicos de solo em sistema de integração lavoura pecuária. Pesq. Agropec. Bras., 46:1301-1309, 2011 b.

DANE, J.H. \& HOPMANS, J.W. Water retention and storage. In: DANE, J.H. \& TOPP, G.C., eds. Methods of soil analysis. Madison, Soil Science Society of America, 2002. Part 4. p.671-720.

ELLERT, B.H. \& BETTANY, J.R. Calculation of organic matter and nutrients stored in soils under contrasting management regimes. Can. J. Soil Sci., 75:529-538, 1996.

EMPRESA BRASILEIRA DE PESQUISA AGROPECUÁRIA EMBRAPA. Manual e métodos de análise de solos. 2.ed. Rio de Janeiro, Embrapa Solos, 2011. 230p.

FERNÁNDEZ, P.L.; ALVAREZ, C.R. \& TABOADA, M.A. Assessment of topsoil properties in integrated croplivestock and continuous cropping systems under zero tillage. Soil Res., 49:143-151, 2011.

FLINT, A.L. \& FLINT, L.E. Particle density. In: DANE, J.H. \& TOPP, G.C., eds. Methods of soil analysis. Madison, Soil Science Society of America, 2002. Part 4. p.229-240.

FLORES, J.P.C.; ANGHINONI, I.; CASSOL, L.C.; CARVALHO, P.C.F.; LEITE, J.G.D.B. \& FRAGA, T.I. Atributos físicos e rendimento de soja e sistema plantio direto em integração lavoura-pecuária com diferentes pressões de pastejo. R. Bras. Ci. Solo, 31:771-780, 2007.

GREGORY, A.S.; WATTS, C.W.; WHALLEY, W.R.; KUAN, H.L.; GRIFFITHS, B.S.; HALLETT, P.D. \& WHITMORE, A.P. Physical resilience of soil to field compaction and the interactions with plant growth and microbial community structure. Eur. J. Soil Sci., 58:1221-1232, 2007.

GROSSMAN, R.B. \& REINSCH, T.G. Bulk density and linear extensibility. In: DANE, J.H. \& TOPP, G.C., eds. Methods of soil analysis. Madison, Soil Science Society of America, 2002. Part 4. p.201-228.

INDA JÚNIOR, A.V.; BAYER, C.; CONCEIÇÃO, P.C.; BOENI, M.; SALTON, J.C. \& TONIN, A.T. Variáveis relacionadas à estabilidade de complexos organo-minerais em solos tropicais e subtropicais brasileiros. Ci. Rural, 37:1301-1307, 2007. 
INTERGOVERNMENTAL PANEL ON CLIMATE CHANGE - IPCC. Fourth assessment report, climate changes 2007: Synthesis report. Cambridge, Cambridge University Press, 2007. 52p.

KAISER, H.F. The varimax criterion for analytic rotation in factor analysis. Psychometrika, 23:178-200, 1958.

KUMAR, S.; UDAWATTA, R.P. \& ANDERSON, S.H. Root length density and carbon content of agroforestry and grass buffers under grazed pasture systems in a Hapludalf. Agrofor. Syst., 80:85-96, 2010.

KUZYAKOV, Y. \& DOMANSKY, G. Carbon input by plants in the soil - Review. J. Plant Nutr. Soil Sci., 163:421-431, 2000 .

LAL, R. Soi carbon sequestration to mitigate climate chance. Geoderma, 123:1-22, 2004

LENKA, N.K.; CHOUDHURY, P.R.; SUDHISHRI, S.; DASS, A. \& PATNAIK, U.S. Soil aggregation, carbon build up and root zone soil moisture in degraded sloping lands under selected agroforestry based rehabilitation systems in eastern India. Agric. Ecosyst. Environ., 150:54-62, 2012.

LIMA, S.S.; LEITE, L.F.C.; OLIVEIRA, F.C. \& COSTA, D.B. Atributos químicos e estoques de carbono e nitrogênio em Argissolo Vermelho-Amarelo sob sistemas agroflorestais e agricultura de corte e queima no norte do Piauí. R. Árvore, 35:51-60, 2011.

MACEDO, M.C.M. Integração lavoura e pecuária: o estado da arte e inovações tecnológicas. R. Bras. Zootec., 38:133$146,2009$.

MAIA, S.M.F.; OGLE, S.M.; CERRI, C.E.P. \& CERRI, C.C. Effect of grassland management on soil carbon sequestration in Rondônia and Mato Grosso states, Brazil. Geoderma, 149:84-91, 2009.

MARCHÃO, R.L.; BALBINO, L.C.; SILVA, E.M.; SANTOS JÚNIOR, J.D.G.; SÁ, M.A.C.; VILELA, L. \& BECQUER, T. Qualidade física de um Latossolo Vermelho sob sistemas de integração lavoura-pecuária no Cerrado. Pesq. Agropec. Bras., 42:873-882, 2007.

MEKONNEN, K.; BURESH, R.J. \& JAMA, B. Root and inorganic nitrogen distributions in sesbania fallow, natural fallow, and maize fields. Plant Soil, 188:319-327, 1997.

MOREIRA, W.H.; BETIOLI JÚNIOR, E.; PETEAN, L.P.; TORMENA, C.A.; ALVES, S.J.; COSTA, M.A.T. \& FRANCO, H.H.S. Atributos físicos de um Latossolo Vermelho distroférrico em sistema de integração lavoura-pecuária. R. Bras. Ci. Solo, 36:389-400, 2012.

NIMMO, J.R. \& PERKINS, K.S. Aggregate stability and size distribution. In: DANE, J.H. \& TOPP, G.C., eds. Methods of soil analysis. Madison, Soil Science Society of America, 2002. Part 4. p.317-328.

PACIULLO, D.S.C.; CASTRO, C.R.T.; GOMIDE, C.A.M.; FERNANDES, P.B.; ROCHA, W.S.D.R.; MÜLLER, M.D. \& ROSSIELLO, R.O.P. Soil bulk density and biomass partitioning of Brachiaria decumbens in a silvopastoral system. Sci. Agric., 67:598-603, 2010.
PACIULLO, D.S.C.; GOMIDE, C.A.M.; CASTRO, C.R.T.; FERNDANDES, P.B.; MÜLLER, M.D.; PIRES, M. F.A.; FERNANDES, E.N. \& XAVIER, D.F. Características produtivas e nutricionais do pasto em sistema agrossilvipastoril, conforme a distância das árvores. Pesq. Agropec. Bras., 46:1176-1183, 2011.

PAUDELS, B.R.; UDAWATTA, R.P.; KREMER, R.J. \& ANDERSON, S.H. Soil quality indicator responses to row crop, grazed pasture, and agroforestry buffer management. Agrofor. Syst., 84:311-323, 2012.

PIETOLA, L.; HORN, R. \& YLI-HALLA, M. Effects of trampling by cattle on the hydraulic and mechanical properties of soil. Soil Till. Res., 82:99-108, 2005.

PULROLNIK, K.; BARROS, N.F.; SILVA, I.R.; NOVAIS, R.F. \& BRANDANI, C.B. Estoques de carbono e nitrogênio em frações lábeis estáveis da matéria orgânica de solos sob eucalipto, pastagem e cerrado no Vale do Jequitinhonha, MG. R. Bras. Ci. Solo, 33:1125-1136, 2009.

REICHERT, J.M.; SUZUKI, L.E.A.S.; REINERT, D.J.; HORN, R. \& HAKANSSON, I. Reference bulk density and critical degreeof-compactness for no-till crop production in subtropical highly weathered soils. Soil Till. Res., 102:242-254, 2009.

ROMANO, N.; HOPMAMS, J.W. \& DANE, J.H. Suction table. In: DANE, J.H. \& TOPP, G.C., eds. Methods of soil analysis. Madison, Soil Science Society of America, 2002. Part 4. p.692-698.

ROSSETI, K.V.; CENTURION, J.F.; OLIVEIRA, P.R. \& ANDRIOLI, I. Atributos físicos nos tempos de adoção de manejos em Latossolo cultivado com soja. R. Bras. Ci. Solo, 36:367-376, 2012

SANTOS, G.G.; MARCHÃO, R.L.; SILVA, E.M.; SILVEIRA, P.M. \& BECQUER, T. Qualidade física do solo sob sistemas de integração lavoura-pecuária. Pesq. Agropec. Bras., 46:1339-1348, 2011.

SILVA, R.F.; GUIMARÃES, M.F.; AQUINO, A.M. \& MERCANTES, F.M. Análise conjunta de atributos físicos e biológicos do solo sob sistema de integração lavourapecuária. Pesq. Agropec. Bras., 46:1277-1283, 2011.

SNEATH, P.H.A. \& SOKAL, R.R. Numerical taxonomy. San Francisco, Freedman \& Company, 1973. 573p.

SOARES, A.B.; SARTOR, L.R.; ADAMI, P.F.; VERELLA, A.C.; FONSECA, L. \& MEZZALIRA, C. Influência da luminosidade no comportamento de onze espécies forrageiras perenes de verão. R. Bras. Zootec., 38:443-451, 2009.

SOUZA, E.D.; COSTA, S.E.V.G.A.; ANGHINONI, I.; CARVALHO, P.C.F.; OLIVEIRA, E.V.F.; MARTINS, A.P.M.; CAO, E. \& ANDRIGHETTI, M. Soil aggregation in a crop-livestock integration system under no-tillage. R. Bras. Ci. Solo, 34:1365-1374, 2010.

TONUCCI, R.G.; NAIR, P.K.R.; NAIR, V.D.; GARCIA, R. \& BERNARDINO, F.S. Soil carbon storage in silvopasture and related land-use systems in the Brazilian Cerrado. J. Environ. Qual., 40:833-841, 2011.

TORMENA, C.A.; SILVA, A.P. \& LIBARDI, P.L. Caracterização do intervalo hídrico ótimo de um Latossolo Roxo sob plantio direto. R. Bras. Ci. Solo, 22:573-581, 1998. 
TRACY, B.F. \& ZHANG, Y. Soil compaction, corn yield response, and soil nutrient pool dynamics within an integrated crop-livestock system in Illinois. Crop Sci., 48:1211-1218, 2008.

XU, X.; NIEBER, J.L. \& GUPTA, S.C. Compaction effect on the gas diffusion coefficient in soils. Soil Sci. Soc. Am. J., 56:1743-1750, 1992.

ZINN, Y.L.; LAL, R. \& RESCK, D.V.S. Eucalypt plantation effects on organic carbon and aggregation of three differenttextured soils in Brazil. Soil Res., 49:614-624, 2011.
ZINN, Y.L.; LAL, R. \& RESCK, D.V.S. Changes in soil organic carbon stocks under agriculture in Brazil. Soil Till. Res., 84:28-40, 2005.

WALKLEY, A. \& BLACK, I.A. An examination of the Degtjareff method for determining soil organic matter and a proposed modiûcation of the chromic acid titration method. Soil Sci., 38:29-38, 1934.

WARD, J.H. Hierarchical grouping to optimize an objective function. J. Am. Stat. Assoc., 58:236-244, 1963. 